\title{
Characters as Works and Versions
}

\author{
John K. Young
}

\begin{abstract}
The editorial conception of works - as immaterial entities emerging from encounters with material documents or other instantiations - parallels conceptions of characters in narrative studies, which similarly derive from particular textual engagements to produce more general understandings. After surveying a range of examples from 20th-and 21st-century fiction, this essay outlines the affordances of a more editorially informed approach to the concept of character within narratology.
\end{abstract}

T

HS ESSAY WILl CLAIM THAT WORKS, UNDERSTOOD IN THE EDITOrial sense, bear fundamental similarities to characters, understood in the narratological sense. Like works, characters are immaterial entities emergent from material documents and the versions they yield, though the case of fiction requires a broader sense of "document", encompassing not just books, periodicals, and digital texts, but also the forms produced by film, television, graphic novels, podcasts, oral storytelling, and even visual arts or music. ${ }^{1}$ Thinking of characters as works, and along the way as versions of works, enables a more thorough understanding of characters conceptually, and especially as entities of change. More broadly, this article is part of an attempt to bridge connections between narrative and editorial theory, a project that has been broadly outlined Lars Bernaerts and Dirk van Hulle, who maintain that "genetic criticism's awareness of the diachronic dimension of writing is directly relevant to the project of narrative theory" (2013, 285). Here I hope to extend those connections through a narrower focus on the notion of character, and through a focus on variants among published versions, rather than solely on the pre-publication materials that are the provenance of genetic criticism. The result will offer, I hope, a small contribution to Paul Eggert's recent call for the "allied testimony of bibliography and book history" as part of a renewed study of "the embodied act

1. On editorial theory and textual scholarship in relation to a wide range of media, see Loizeaux and Fraistat 2002. For an insightful discussion of character in relation to seriality (or "personnel"), see O'Sullivan 2019, 58-9. 
of reading in the here and now" $(2019,18)$, with "reading" here understood to comprise all manners of texts and their audiences. While narratology tends to think of characters in terms of individual inscriptions rather than as a more collective entity derived from multiple documents and versions, a more bibliographically inclined approach should demonstrate both the material processes through which narratives are produced and the conceptual clarity with which we might understand them along a materialimmaterial axis.

I address Eggert's recent thoughts on the notion of the work in more detail below, as part of a survey of approaches to the concept within editorial theory, but I begin with a brief claim from Eggert's The Work and The Reader in order to elucidate the kinds of connections I will seek to draw to narratology's understanding of character. As part of his argument that the work should be understood as a kind of regulative ideal (not quite in the Kantian sense), ${ }^{2}$ which develops from material documents, Eggert concludes: "The name of the individual work is the container that we project from the document for the textual and other meanings we raise or extrapolate from our dealings with it. If such is the case then the work is better understood phenomenologically than ontologically, with emphasis put on the role of readers in the functioning of the work" $(2019,33)$. If we substitute "character" for "work" in this statement, the kinds of connections I intend should become apparent: audiences interpret characters and understand them within the scope of a larger narrative, projecting meanings onto the "container" that is the idea of a character, and so go about the narrative business of referring to characters beyond the bounds of their documentary origins, responding to the material-immaterial axis of character in very much the same ways that inhere for an experience of the work.

Before delving into these waters further, I will begin with a few brief examples. Consider the character of Annie Wells in Don Lee's story "The Lone Night Cantina", who frequents the cowboy bar of the title, much to her sister's dismay, in a mostly unsuccessful search for love. That is the character's name in the 1987 version of the story, published in Ploughshares, but in the 2001 version, published in Lee's collection Yellow, the character becomes Annie Yung, changing in the process from a white woman to a Korean American one. Lee completed the magazine version of the story several years before he realized he was going to produce a book called Yellow, which collects stories focusing primarily on Asian American charac-

2. I develop this distinction in greater detail in my review of Eggert's The Work and the Reader in Script EF Print 44.1 (2021): 43-6. 
ters in the fictional California town of Rosarita Bay. The "cowboy myth" pursued by Annie Wells in the magazine story, who readers take to be white, as Toni Morrison would put it, because nobody says so, takes on a potentially different valency for Annie Yung in the book version (where her sister Evelyn's racial identity is similarly revised). We find related changes in Lee's story "El Niño", published in GQ in 1989, where a biographical note informed readers that "Don Lee is working on a collection of Rosarita Bay stories called The Plumb Line", and that story's version as "Widowers" in Yellow, by which point Lee had understood the stories of The Plumb Line in a different context. Emily Ross in "El Niño", whose "skin was white, unblemished except for a small line of a scar above her left eye" (LeE 1989, 226), becomes Emily Viera Ross, "an Asian of indeterminate origin" (LeE 2001, 79) in "Widowers", and Lee transforms her white lover in the magazine version, Dale Burkman, into the Japanese American character Alan Fujitani in the Yellow chapter. Only in the book version, then, does Alan Fujitani mention a beachfront house that has been in his family for four generations, "excepting the three years they were interned at Manzanar", a so-called "War Relocation Center" opened after Pearl Harbor (LeE 2001, 82). As Kun Jong Lee concludes of Don Lee's "change in concept of his cycle from a collection linked by place to one focusing on Asian American experiences", the "the Asian American writer made an 'Asian American' short-story cycle par excellence by coloring his magazine stories yellow" (LeE 2015, 596). ${ }^{3}$ In bibliographic terms, we might say that Lee's "developing version" of The Plumb Line resulted in an "essayed version" (SHILLINGSBuRg 1997, 68) of "El Niño", and then in a different essayed version of "Widowers", once Lee had abandoned the idea of the Plumb Line connection in favor of Yellow as a work. ${ }^{4}$

Here is another example that works in more or less the same ways, though with more complicated outcomes. In Tim O'Brien's 1994 novel In the Lake of the Woods, the protagonist John Wade is a veteran of the American war in Viet Nam. Readers learn, gradually, that Wade has been a member of the notorious Charlie Company at My Lai, and that he has spent years concealing this information from everyone, including his political constituency - Wade is a Democratic politician from Minnesota whose campaign for a Senate seat crashes when his presence at My Lai finally

3. See LEE 2015 for a more detailed discussion of the various changes between magazine and book versions of Don Lee's stories.

4. For a more extensive discussion of the conceptual relationships between magazine texts and their book forms, see Young 2018. 
becomes public - and even from his wife, Kathy, who disappears shortly after the couple's retreat to a remote cabin, and who may or may not have been murdered by her husband. At different points in the development of the novel, we find different information ascribed to Wade. In O'Brien's early notes and drafts, for instance, Wade loses the primary election not for any reason related to the war, but because he supports unilateral nuclear disarmament (we can easily imagine why O'Brien might have changed this bit of information, as it hardly motivates our impression of Wade as a potential murderer). More importantly for my purposes, in a story published two years before the novel in The Atlantic, titled "The People We Marry", which corresponds to the novel's seventh chapter, "The Nature of Marriage", Wade serves not in William Calley's unit but in Bravo Company. This change may at first glance seem to remove Wade from complicity in My Lai altogether, though Bravo Company's soldiers were in fact part of a parallel operation a few miles away where they also slaughtered dozens of civilians, as Michael Bilton and Kevin Sim point out in their history of the war, which O'Brien's novel frequently cites in its footnotes (BILTON AND Sim 1992, 273). While the magazine story includes several other different pieces of information about other members of Wade's unit, this is the only one that changes for Wade himself.

The textual thread is even more tangled for O'Brien's story "Loon Point", which appeared in Esquire in 1993, and which he then repurposed as chapters both in In the Lake of the Woods and in his 2002 novel July, July. "Loon Point" portrays a weekend outing for Ellie Abbott and a dentist named Harmon, who are in the midst of an affair, until Harmon dies suddenly and Ellie returns home to her unsuspecting husband. In Lake, this story appears as a memory for Kathy Wade - the other man is still Harmon the dentist, with Kathy in the role of Ellie. But in July, July, we find much the same story as in "Loon Point", though now transferred to an older Ellie Abbott, again, who is 52 in the novel but 37 in the magazine story. ${ }^{5}$

These examples point to instances where a fundamentally defining aspect of a character - racial or ethnic identity, or a transformational experience - exist in multiple versions, suggesting, as I will argue below, that readers' senses of these characters should necessarily adjust along the way. But a look at versions of characters finds a wide range of types of change. In fictions by Jennifer Egan and Evelyn Waugh, for example, characters change not in the ascription of defining properties, but in relation to

5. For a more detailed discussion of these examples, see Young 2017, 148-55 and $166-9$. 
broader narrative dynamics. The "Safari” chapter of Jennifer Egan's 2010 novel A Visit from the Goon Squad contains a rather remarkable moment of prolepsis:

The warrior smiles at Charlie. He's nineteen, only five years older than she is, and has lived away from his village since he was ten. But he's sung for enough American tourists to recognize that in her world, Charlie is a child. Thirty-five years from now, in 2008, this warrior will be caught in the tribal violence between the Kikuyu and the Luo and will die in a fire. He'll have had four wives and sixty-three grandchildren by then, one of whom, a boy named Joe, will inherit his lalema: the iron hunting dagger in a leather scabbard now hanging at his side. Joe will go to college at Columbia and study engineering, becoming an expert in visual robotic technology that detects the slightest hint of irregular movement (the legacy of a childhood spent scanning the grass for lions). He'll marry an American named Lulu and remain in New York, where he'll invent a scanning device that becomes standard issue for crowd security. He and Lulu will buy a loft in Tribeca, where his grandfather's hunting dagger will be displayed inside a cube of Plexiglass, directly under a skylight.

(2010b, 61-2).

But when that chapter appeared in a January 2010 issue of The New Yorker, the paragraph read simply, "The warrior smiles at Charlie. He's nineteen, and has lived away from his village since he was ten. But he has sung for enough American tourists to recognize that, in her world, Charlie is a child" (EgAN 2010a, 69). When Egan submitted "Safari" to the New Yorker, she presumably had either not yet finished writing Goon Squad, and so retroactively inserted a proleptic intrusion once the character of Joe had made his way into Lulu's story and would figure in the book's later chapters, or chose to keep the magazine's story, as a separately published text, within a tighter temporal focus. In either case, the reader of the magazine version is not called suddenly forward several decades, only incorporating this report of the "warrior" into an ongoing understanding of the narrative within a single time frame.

In the case of Waugh's 1934 novel A Handful of Dust, the first, British, edition concludes with the protagonist, Tony Last, trapped in a Brazilian jungle with an insane man (who forces him to read aloud from Charles Dickens all day). Last's wife presumes him to be dead and so marries a mutual friend back in England. Spurred by copyright law peculiarities to rewrite the final scene for an American magazine version, Waugh produced 
the opposite ending: Tony Last returns from a cruise, never having been taken prisoner, and reconciles with his spouse back in England. ${ }^{6}$ While readers' senses of these characters may not change dramatically across versions, clearly their place within the broader spectrum of the storyworld is importantly different in each case.

Finally, I turn briefly to a subtler shift, though one that still presents ripple effects in readers' phenomenological experiences. Virginia Woolf's To the Lighthouse famously concludes section XIX of "The Window" with a scene of reconciliation between Mr. and Mrs. Ramsay, in which Mrs. Ramsay at last acquiesces to her husband's unspoken demands for affection by admitting that the next day's weather will make a trip to the lighthouse impossible. This scene is usually quoted, from the American edition first published by Harcourt Brace in 1927, as follows:

"Yes, you were right. It's going to be wet tomorrow. You won't be able to go". And she looked at him smiling. For she had triumphed again. She had not said it: yet he knew.

The last sentence's statement of mutual knowledge prompts Martha Nussbaum's investigation of the novel in terms of the problem of other minds, as evidence for her larger conclusion that "Knowledge, in short, is a function of character" (1995, 749), among numerous other related studies.? But these lines appeared only in the American first edition; the British first edition, which appeared on the same day in 1927 from Woolf's own Hogarth Press, ends "The Window" simply with Mrs. Ramsay's triumph. As Hans Walter Gabler has shown, the textual evidence here leads to the conclusion that "either ending of the 'Window' section is a real and valid textual option" (GABLER 2004, 14), part of what Julia Briggs demonstrates to be Woolf's broader tendency, in her capacity as author-publisher, toward

6. See Davis 1969.

7. Nussbaum is hardly alone in her focus on this key passage. Roberta Rubenstein, for instance, citing the Harcourt Brace 1981 reprint of the original American edition, concludes, "The closing passage of the novel's first section thus demonstrates Woolf's complex use of negative language, which modulates to encompass not only Mr. Ramsay's emotional neediness and Mrs. Ramsay's acquiescence to it but the triumph of their mutual intimacy and affection over negation" (2008, 42). 
a "refusal to provide a definitive or final version" of her works (BRIGGS 2006, 209).

Drawing on these examples (and others like them) I'm interested here in both the theory and practice of fictional characters - how to understand them (as "model persons", as cultural artifacts, as incomplete objects) and how to reconcile those understandings with particular instances of characters, especially characters that exist in importantly different versions. I should note that there are different versions of what one might mean by "versions of characters". Uri Margolin, for instance, in an essay titled "Characters and Their Versions", focuses primarily on instances of adaptation, such as the character of Grendel in John Gardner's novel or the Biblical figure of Joseph in Thomas Mann's fiction, in addition to the problem of historical figures being referred to in fictional worlds (where the Napoleon in War and Peace seems to be a version of the "real" Napoleon, for example). From a transmedial standpoint, we might revisit Margolin's approach to account for the various versions of a character across media, or to think about the various incarnations of a character in performance history, assuming we were to identify the version of Cordelia in Shakespeare's day as distinct, say, from 19th-century versions of the character, and in turn not quite the same as 20th- and 21st-century incarnations. None of these are exactly what I have in mind here, though I will return to Margolin's essay for some helpful insights at the end of this essay.

In order to flesh out these kinds of conceptual connections between experiences of works and characters, I will briefly rehearse the major ways to define the concept of character within narratology, while, admittedly, largely glossing over important distinctions and debates on these issues. I should also note that, for the sake of relative simplicity, I have not referred in my examples to unnatural characters, though my conclusions about characters as works would apply equally in those cases — and we might think of characters read collectively across versions as unnatural in a certain sense, as a single character exhibiting opposing characteristics would certainly have unnatural effects. At least as a starting point, though, narratologists focusing primarily on realistic fiction and those working on unnatural narratives concur on the basis for how audiences apprehend characters. Robyn Warhol, for instance, writes: "Characters are marks on the page, made up of the alphabetical characters that spell out 'who' they are. [. . .] Characters are the representational effects the novelist creates in structuring the novel" (Herman et. Al. 2012, 119). Brian Richardson, similarly, notes that, "Characters in fiction are, after all, words on a page" (Herman ET. AL. 2012, 133). From those words on a page, narratology typically sees read- 
ers ascribing properties to characters, in terms of behaviors, appearances, speech, and personality features. David Herman, while thinking of characters as "model persons", retains Seymour Chatman's sense of characters as derived from a "vertical assemblage" of properties, based on the ways that "textual cues prompt interpreters to map person-like traits onto individuals represented in narratives" (Herman ET. AL. 2012, 129). Within a rhetorical approach, characters also appear as "artificial constructs" that "resemble possible people", as James Phelan and Peter Rabinowitz put it (Herman et. Al. 2012, 111). And Marie-Laure Ryan, in what she labels a "worlds approach" to this issue, merging "textualist" and philosophical perspectives, highlights the audience's experience of characters, in which they "can be regarded as both human beings and as textual constructs" (2018, 426). While I'm sidestepping here philosophical accounts that perceive characters as inhabitants of possible worlds, or alternatively as cultural artifacts, I would note in passing that both those starting points still rely on textual representations (broadly construed) as the groundwork for the entities being referred to as "characters".

For my purposes, the key point here would be the importance of the text - the book or magazine at hand, the film or TV show on screen, the theatrical performance, the video game, etc. - as the necessary starting point for perceiving and understanding characters. That is, there is a material instantiation of a text of whatever kind that audiences first encounter on their way to identifying entities as characters. Philosophical accounts of the work of art typically start from a similar premise (though I'm again oversimplifying a substantial and complex history here). For most philosophers of aesthetics, the "work" constituted by a musical score, for instance, is not reducible to the physical inscription of the score, nor to a particular performance of those notes, but instead operates as an immaterial sense, which is derived from the material instantiations of the score (or versions of the score) and its multiple performances. Similarly, a work of literature would derive from a necessary engagement with its material incarnations, but is itself an immaterial entity - Beloved as a work, say, does not reside in any copy of that novel, though it depends on readers' encounters with those physical objects. Peter Lamarque summarizes this position: "To have heard a performance of the Moonlight Sonata is to have heard the Moonlight Sonata, just as to have read a copy of Pride and Prejudice is to have read

8. For an overview of philosophical approaches to character, see LivingSTON AND SAUchelli 2011. For further discussion of characters in relation to philosophical conceptions of the work of art, see Thom Asson 1999, Ch. 5. 
Pride and Prejudice. Yet neither that performance nor that copy is identical with the works in question for the latter could exist without the former" (2002, 142).

Within editorial theory, a similar consensus holds (with equally important distinctions and debates, also elided here) on the relationship between individual documents and the works derived from them. Gabler, for instance, enunciates a "fundamental distinction" between texts and works: "'text' is always grounded in the materiality of transmissions, while 'work' is conceptually always immaterial" $(2018,7)$. Similarly, Barbara Bordalejo concludes, "Traces of the work, evidence of its existence, can be found in the documents and the texts they hold, but the work itself is none of those instances while, at the same time, is somehow present in all of them" (2013, 71). Eggert offers another version, so to speak, of this conceptualization, thinking of "workhood" as deriving from a "shared projection of a regulating idea" of the work $(2019,33)$. Again thinking of Beloved (or any work) from an editorial perspective, one would say that the collection of documents related to Beloved as a work, here including Morrison's drafts and notes along with the various published editions, would comprise Beloved as a work, but would not contain Beloved as a work within one or more (or even all) of those documents.

This should sound more or less similar, I hope, to both philosophical conceptions of the work of art, and to narratological conceptions of character. While narrative theorists typically would not put the matter in quite these terms, I would suggest that they are, fundamentally, thinking of characters in the same ways that philosophers of aesthetics and editorial theorists are thinking of works - that is, characters are based on material inscriptions (words on a page) but are not reducible to a particular instance of inscription. While it might well be useful to have a copy of Beloved at hand to refer to the character of Denver, for instance, it is not necessary - we can think of a character apart from the material text in which it has been delivered, though encountering the character in that physical environment is a necessary first step on the way to that immaterial understanding. This material-immaterial relation also partly accounts for the ability to perceive transmedial characters, to recognize Emma Woodhouse as the "same" character in Austen's novel or in any of its many film, television, digital, theatrical, or manga adaptations, not to mention the many other books by other authors producing various versions of Emma. In these cases, characters, as Peter Shillingsburg writes of works, "are variously implied by their material representations; they are represented materially and virtually, 
and they are interpreted variously by authors, publishers, editors, and other readers" $(2017,121)$.

Thinking of characters as works is also especially helpful, I will conclude, in the kinds of cases I outlined earlier, in which particular traits ascribed to those characters, or particular actions associated with those characters, threaten to cancel each other out across different versions. For Margolin, this kind of change in versions of a character is not a problem, as long as, crucially, they occur along different timelines within the relevant storyworlds. As he concludes, "incompatible sets of properties assigned to an IND [Margolin's abbreviation for an individual within a fictional world] with the same proper name can, in principle, be joined into one source book on him [sic.] as long as they take different temporal evaluations" $(1996,122)$. The examples I have cited, however, are not instances of characters changing across time (that is, across the time of the storyworlds they inhabit), though they are changing across the time of their textual production (except in the simultaneous case of the two editions of To the Lighthouse). While it would seem "incompatible", in Margolin's terms, to say that Annie Wells and Annie Yung are the "same" character, or to say that John Wade was and was not present at the My Lai massacre, or to say that Tony Last was and was not held hostage in Brazil, or that the unnamed African's dagger will or will not (or perhaps may not) be displayed in his grandson's New York apartment, the editorial notion of the work, I think, offers a solution to this problem. (The alternative solution, of course, would be to claim that these are not the same characters, but this answer would founder quite quickly on the problem that they have so many other actions and properties in common.) Just as we would think, editorially, of these magazine stories and novels as parts of larger works, which could comprise important differences in story and discourse, so too might we think of characters in this broader sense. This kind of approach would afford a more expansive view of character across versions and contribute to a deeper sense of characters and texts in relation to the histories of their production within narratological analysis.

\section{Works Cited}

Bernaerts, Lars, and Dirk van Hulle. 2013. "Narrative Across Versions: Narratology Meets Genetic Criticism”. Poetics Today 34.3: 281-326.

Bilton, Michael, and Kevin Sim. 1992. Four Hours in My Lai. New York: Penguin. 
Bordalejo, Barbara. 2013. "The Texts We See and the Works We Imagine: The Shift of Focus of Textual Scholarship in the Digital Age". Ecdotica 10: 64-76.

Briggs, Julia. 2006. Reading Virginia Woolf. Edinburgh: Edinburgh University Press.

Davis, Murray. 1969. “'Harper's Bazaar' and 'A Handful of Dust”. Philological Quarterly 48.4: 508-16.

EgAn, Jennifer. 2010a. "Safari”. The New Yorker, 4 January: 66-73.

- 2010b. A Visit from the Goon Squad. New York: Alfred A. Knopf.

Eggert, Paul. 2019. The Work and the Reader in Literary Studies: Scholarly Editing and Book History. Cambridge: Cambridge University Press.

Gabler, Hans Walter. 2004. "A Tale of Two Texts: Or, How One Might Edit Virginia Woolf's To the Lighthouse". Woolf Studies Annual 10: 1-29.

- 2018. Text Genetics in Literary Modernism and Other Essays. Cambridge: Open Book Publishers.

Herman, David, James Phelan, Peter J. Rabinowitz, Brian Richardson, Robyn Warhol. 2012. Narrative Theory: Core Concepts $\mathcal{E}$ Critical Debates. Columbus: Ohio State University Press.

Lamarque, Peter. 2002. "Work and Object". Proceedings of the Aristotelian Society 102.1: 141-62.

LeE, Don. 1987. “The Lone Night Cantina”. Ploughshares 13.2-3: 190-212. 1989. "El Niño". GQ 59.10: 224-36.

2001. Yellow: Stories. New York: W.W. Norton.

LeE, Kun Jong. 2015. "The Making of an Asian American Short-Story Cycle: Don Lee's Yellow: Stories”. Journal of American Studies 49.3: 593-613.

Livingston, Paisley, and Andrea Sauchelli. 2013. "Philosophical Perspectives on Fictional Characters". New Literary History 42.2: 337-60.

Loizeaux, Elizabeth Bergman, and Neil Fraistat. 2002. "Introduction: Textual Studies in the Late Age of Print". In Reimagining Textuality: Textual Studies in the Late Age of Print, edited by Elizabeth Bergman Loizeaux and Neil Fraistat. Madison: University of Wisconsin Press: 3-16.

Margolin, Uri. 1996. "Characters and Their Versions". In Fiction Updated: Theories of Fictionality, Narratology, and Poetics, edited by Calin Andrei Minailescu and Walid Hamarneh. Toronto: University of Toronto Press: 112-32.

Nussbaum, Martha. 1995. "The Window: Knowledge of Other Minds in Virginia Woolf's 'To the Lighthouse”. New Literary History 26.4: 731-53.

O’Brien, Tim. 1992. “The People We Marry”. Atlantic Monthly, January: 90-8. 1993. "Loon Point". Esquire, January: 90-4.

1994. In the Lake of the Woods. Boston: Houghton Mifflin.

O'Sullivan, Sean. 2019. "Six Elements of Serial Narrative". Narrative 27.1: 49-64.

Rubinstein, Roberta. 2008. "I Meant Nothing by the Lighthouse': Virginia Woolf's Poetics of Negation". Journal of Modern Literature 31.4: 36-53.

Ryan, Marie-Laure. 2018. "What are characters made of? Textual, philosophical, and 'worlds' approaches to character ontology". Neohelicon 45: 415-29. 
Shillingsburg, Peter L. 1997. Resisting Texts: Authority and Submission in Constructions of Meaning. Ann Arbor: University of Michigan Press.

2017. Textuality and Knowledge: Essays. University Park: Pennsylvania State University Press.

Thom asson, Amie L. 1999. Fiction and Metaphysics. Cambridge: Cambridge University Press.

Young, John K. 2017. How to Revise a True War Story: Tim O'Brien's Process of Textual Production. Iowa City: University of Iowa Press.

— 2018. "The Editorial Ontology of the Periodical Text". Ecdotica 15: 88-128. 